\title{
Diversity and antagonistic potential of bacteria isolated from marine grass Halodule uninervis
}

\author{
Fehmida Bibi ${ }^{1}$ - Muhammad Imran Naseer ${ }^{3}$. Ahmed Mohamad Hassan ${ }^{1}$ - Muhammad Yasir ${ }^{1}$. \\ Ahmed Abdullah Khalaf Al-Ghamdi · Esam Ibrahim Azhar ${ }^{1,2}$
}

Received: 21 September 2016 / Accepted: 26 December 2017 / Published online: 3 January 2018

(c) Springer-Verlag GmbH Germany, part of Springer Nature 2018

\begin{abstract}
The aim of this study was to isolate bacteria from sea grass, Halodule uninervis collected from the coastal area of Jeddah, Saudi Arabia and to screen them for antifungal and enzymatic activities. We have isolated 162 rhizo and endophytic bacteria from soil, roots, and leaves of the sea grass. Antifungal screening of isolated bacteria revealed 19 strains (11.7\%) capable to inhibit growth of four pathogenic fungi, Pythium ultimum, Phytophthora capsici, pyricularia oryzae, and Rhizoctonia solani in an in vitro assay. Taxonomic and phylogenetic analyses on the basis of 16S rRNA gene sequence revealed 97-99.9\% sequence identity to recognized species. Bacillus, Staphylococcus, Jeotgalicoccus, and Planococcus, within the Phylum Firmicutes, Kocuria, Arthrobacter, Ornithinimicrobium and Corynebacterium (Actinobacteria), Sulfitobacter, Roseivivax, Ruegeria ( $\alpha$-Proteobacteria), Moraxella, and Vibrio ( $\gamma$-Proteobacteria), were isolated. Strains belong to Phylum Firmicutes remain dominant antagonistic bacteria in this study. Further hydrolytic enzyme production was determined for these antagonistic bacteria. Our results demonstrated that the sea grass represents an important source of diverse antagonistic bacteria capable of producing antifungal metabolite.
\end{abstract}

Keywords Sea grass $\cdot$ Antagonistic bacteria $\cdot$ Pathogenic fungi $\cdot 16 \mathrm{~S}$ rRNA gene sequence $\cdot$ Phylogenetic analysis

\section{Introduction}

Marine environment is a reservoir of many novel bioactive compounds. Until now, thousand of unique compounds have been isolated from marine environment (Ireland et al. 1993; Newman and Cragg 2004; Hu et al. 2015). In past, for the discovery of a new compound, different marine samples from marine environment have been searched. Many studies have reported the antagonistic bacterial communities associated with marine plants suggesting their beneficial role in plants (Shin et al. 2007; Bibi et al. 2012). In this mutualistic

Fehmida Bibi

fnaseer@kau.edu.sa

1 Special Infectious Agents Unit, King Fahd Medical Research Center, King Abdulaziz University, Jeddah, Saudi Arabia

2 Department of Medical Laboratory Technology, Faculty of Applied Medical Sciences, King Abdulaziz University, Jeddah, Saudi Arabia

3 Center of Excellence in Genomic Medicine Research (CEGMR), King Abdulaziz University, Jeddah 21589, Saudi Arabia relationship, microbial communities in marine environment help plant in different processes such as growth promotion, nitrogen fixation, remediation of different contaminants, and defense against different pathogenic microbes and in turn plant provide shelter to microbes (Singh and Reddy 2014). Antagonistic microbes associated with marine plants are believed to produce some bioactive compounds to protect host plant from diseases and predators (Bhatnagar and Kim 2010). Therefore, marine environment is widely considered as promising source of identifying new bacteria and their novel metabolites.

Marine bacteria are distributed widely in marine areas from intertidal to deep sea and also in extreme places such as hydrothermal and polar sea. This describes their implausible tendency to adapt to different environment by developing different approaches to survive. These approaches include their ability to produce different metabolic pathways in competitive environment of sea (Harvey 2008). This is the reason that most of the marine antimicrobial compounds previously reported are originated from marine host surface-attached bacteria (Shin et al. 2007; Chen et al. 2012). 
Sea grasses provide habitat to various coastal marine organisms. Microbial communities of sea grasses play an important ecological role in marine environment (Pereg et al. 1994; Marhaeni et al. 2011). Many previous studies have reported rhizo and endophytic population of bacteria from sea grasses (García-Martínez et al. 2005; Jensen et al. 2007; Bagwell et al. 2002; Garcias-Bonet et al. 2016). There are several studies related to secondary metabolites production by sea grasses to protect themselves from marine pathogens (Zidorn 2016). Whereas, studies related to isolation of bacteria producing antagonistic metabolites from sea grasses are very few.

The Red Sea is characterized by a unique epipelagic zone with high temperature and salinity, unique coral reef systems, and marine biota. Hence, these components help in the production of unique microbial communities and secondary metabolites. In the Kingdom of Saudi Arabia, the Red sea has not been explored enough for biotechnological and biopharmaceuticals purposes. Focusing on this, and considering the importance of sea grasses and their antagonistic bacterial communities, we have selected sea grass Halodule uninervis for isolation of bacteria from the Red sea coast in Jeddah. Therefore, this study was undertaken to isolate and screen bacteria for their antifungal activity from sea grass $H$. uninervis, and furthermore, these bacteria were assayed for their potential to produce hydrolytic enzymes.

\section{Materials and methods}

\section{Sample collection and isolation of bacteria}

Plant specimens were collected from the coastal area of Obhur, Jeddah, Saudi Arabia (N21 42'57"; E394'48"). Plant specimens were placed in sterile bag and transferred to laboratory for bacterial isolation. For the isolation of bacteria from adhering soil, root was dipped in sterile distilled water to remove adhering soil and serially dilutions were made $\left(10^{-3}, 10^{-4}\right.$, and $\left.10^{-5}\right)$ in autoclaved filtered sea water (AFS) and spread on one-tenth strength R2A (1/10 R2A), nutrient agar in $50 \% \mathrm{FS}$, and Zoebell marine agar. Roots and leaves were also used for isolation of bacteria by washing several times with sterile distilled water to remove any contamination with soil. For isolation of endophytic bacteria from roots and leaves, sterilization procedure was carried out as described before (Bibi et al. 2012). After the sterilization of roots and leaves, about $1.0 \mathrm{~g}$ of each segments of roots and leaves were crushed using sterile mortar and pestle. Aliquots $(0.1 \mathrm{ml})$ were serially diluted $\left(10^{-3}, 10^{-4}\right.$, and $10^{-5}$ ) using AFS and spread on media mentioned above. To avoid contamination, $50 \mu \mathrm{g} / \mathrm{ml}$ cycloheximide was mixed to the medium before pouring. The plates were incubated at $26{ }^{\circ} \mathrm{C}$ for almost 2 weeks and pure colonies were picked and streaked further for bioassay. For further use, the strains were subcultured and stored in $15 \%(\mathrm{v} / \mathrm{v})$ glycerol stock of media at $-80{ }^{\circ} \mathrm{C}$.

\section{Detection of antagonistic activity against fungal pathogens}

Antagonistic assay of bacteria isolated from soil, roots, and leaves was determined by checking fungal pathogens' growth inhibition using a confrontation bioassay. The plant pathogenic fungi, Pythium ultimum, Phytophthora capsici, pyricularia oryzae, and Rhizoctonia solani, were obtained in this laboratory. Antagonistic assays against pathogenic fungi were performed using half-strength (1/2) R2A and $1 / 2$ PDA in $50 \%$ filtered seawater. All the isolated bacteria were streaked at equidistant places in the plates and mycelial disc of fungal pathogens was placed in the centre of the plate and incubated at $28{ }^{\circ} \mathrm{C}$ for $2-4$ days. All isolated strains were checked for antagonistic activity in two independent replicates. The antagonistic activity was then checked by measuring the fungal mycelial inhibition area around the bacterial colony.

\section{Extraction of bacterial DNA and 16S rRNA gene sequencing}

The 19 antagonistic strains were further used for genomic DNA extraction using DNA extraction kit (Thermo Scientific, Waltham, USA) for $16 \mathrm{~S}$ rRNA gene sequencing to identify bacterial strains. The $16 \mathrm{~S}$ rRNA gene fragment was amplified using bacterial universal primers $27 \mathrm{~F}$ (5'-AGA GTTTGATCCTGGCTCAG-3') and 1492R (5'-GGTTAC CTTGTTACGACTT-3'). Amplifications were performed as described previously (Bibi et al. 2012). The PCR products were purified using PCR purification kit (Thermo Scientific, Waltham, USA) and were sequenced by Macrogen (Seoul, Korea). To determine the phylogenetic placement of antagonistic bacteria and related-type strains, the 16S rRNA gene sequences of related-type strains sequences were obtained from National Center for Biotechnology Information (NCBI). For phylogenetic analysis, multiple alignments of the sequences were performed using CLUSTALX (Thompson et al. 1997), and using the BioEdit software (Hall 1999), gaps were edited. The phylogenetic tree based on 16S rRNA gene sequences was constructed using the neighbor-joining method in a MEGA6 Program with bootstrap values based on 1000 replications (Tamura et al. 2013).

\section{Production of hydrolyzing enzymes}

From these antagonistic bacteria, production of fungal cell wall hydrolysis enzymes was measured. Amylase activity was determined according to described method (Kumar et al. 
2012). To determine cellulase activity carboxymethylcellulase (CMC), agar media were used as described previously (Hendricks et al. 1995). Clear zone around bacterial colonies on CMC agar indicates positive activity. Antagonistic bacteria were further screened for proteolytic activity using skim milk $1 / 2 \mathrm{R} 2 \mathrm{~A}$ agar plates containing $10.0 \mathrm{gl}^{-1}$ of skim milk. The isolates showing zones of skim milk clearance are designated as protease producing bacteria. Lipase activity of the antagonistic isolates was detected on tributyrin $1 / 2 \mathrm{R} 2 \mathrm{~A}$ agar plates containing $1 \%(\mathrm{v} / \mathrm{v})$ of tributyrin. Lipase-producing bacteria make clear zones by hydrolysis of tributyrin.

\section{Nucleotide sequence numbers}

In this study, nucleotide sequences of 19 antagonistic strains have been deposited in the GenBank database under accession numbers KT989842-KT989860.

\section{Results}

\section{Isolation of rhizo and endophytic bacteria}

To determine the rhizo and endophytic bacterial population in marine grass, H. uninervis, and soil attached with soil, roots, and leaves samples, have been used for isolation of bacteria. For isolation, different culturing media were used in different concentrations to increase recovery of bacterial population from different parts of plants. A total of 162 morphologically distinct bacterial strains were isolated from rhizo and endosphere of $H$. uninervis, growing in the coastal area of Jeddah during Nov 2015. Majority of the bacterial strains $(40.7 \%)$ were isolated from rhizosphere. While from root, 38.2 and $22.2 \%$ were obtained from leaf using different culturing media.

\section{Screening of bacteria on the basis of antifungal activity}

All isolated strains of bacteria were screened for their inhibitory activity against oomycetes pathogenic fungi, $P y$. ultimum and $P$. capsici in an in vitro assay and active one were further tested for other fungal pathogens, i.e., $P$. oryzae and $R$. solani. Of the 162 tested bacteria, only 19 (11.7\%) exhibit inhibitory activity against fungal pathogens used. Activity of these bacteria against Py. ultimum was significant as compared to $P$. capsici. All active isolates also showed activity against two other fungi, where stronger inhibition was observed against $P$. oryzae $(84.2 \%)$ as compared to $R$. solani (36.8\%) (Table 1$)$. From root, more number of antagonistic bacteria $(52.6 \%)$ were isolated as compared to soil (36.8\%) and leaves (10.5\%). Among the 19 antagonistic bacteria, Bacillus and Staphylococcus were dominant genera followed by species of Vibrio and Kocuria. The strong fungal inhibition was observed for rhizospheric strains EA25 and EA28 with 9-12 mm mycelial inhibition of oomycetes. Another endophytic strain EA44 showed same spectrum of fungal mycelia inhibition with 9-12 mm (Table 1). The antagonistic rhizobacteria EA27 and EA31 had weak inhibition activity $(3 \mathrm{~mm},+)$ against oomycetes pathogens and both were inactive against $P$. oryzae and $R$. solani. While rest of the strains showed moderate activity (4-6 mm). Endophytic isolates from roots and leaves also showed weakto-moderate activity.

\section{Identification of antagonistic bacteria and their phylogenetic analysis}

Antagonistic rhizo and endophytic bacteria were further identified by partial $16 \mathrm{~S}$ rRNA gene sequence analysis. Thirteen different genera were encountered and further assigned to four major classes: Firmicutes $(n=8 ; 42.1 \%)$, Actinobacteria $(n=5 ; 26.3 \%)$, $\alpha$-Proteobacteria $(n=3 ; 15.7 \%)$, and $\gamma$-Proteobacteria $(n=3 ; 15.7 \%)$ (Fig. 1$)$.

Phylogenetic analysis was carried out and a tree was constructed from the data using the neighbor-joining method (Fig. 2). Phylogenetic tree based on 16S rRNA gene sequences obtained from this study and data retrieved from NCBI for closely related strains have shown significant branching patterns with high bootstrap values (100\%) (Fig. 2). The antagonistic bacterial strains exhibited sequence similarity of $96.6-99.9 \%$ with the relatedtype strains. High bootstrap values have been observed for strains of all representative classes. The dominant phylum of antagonistic strains was Firmicutes (42.7\%), where Bacillus was the dominant genus, and revealed their broad distribution among the host plant (Fig. 1). The antagonistic rhizo and endophytic bacteria from phylum Firmicutes were comprised of the 4 genera, Bacillus $(n=3 ; 37.5 \%)$, Staphylococcus $(n=3 ; 37.5 \%)$, Jeotgalicoccus $(n=1 ; 12.5 \%)$, and Planococcus $(n=1 ; 12.5 \%)$. Actinobacteria $(n=5$; $26.3 \%$ ) with the sequence similarity of $97.7-99.4 \%$ were accounted for different parts of the host plant. Actinobacteria comprised of four different genera, mainly Kocuria ( $n=2 ; 40 \%)$, Arthrobacter $(n=1 ; 20 \%)$, Ornithinimicrobium $(n=1 ; 20 \%)$, and Corynebacterium spp. $(n=1 ; 20 \%)$. Actinobacteria were mainly recovered from roots of host plant. The antagonistic rhizo and endophytic bacteria from class Proteobacteria were belonged to $\alpha$-Proteobacteria and $\gamma$-Proteobacteria. Both these subdivisions were comprised of six rhizo and entophytic bacteria with the similarity of $16 \mathrm{~S}$ rRNA gene sequence 97.0-99.9\%. The antagonistic isolates belonging to class Proteobacteria comprised of five genera (Table 1). 


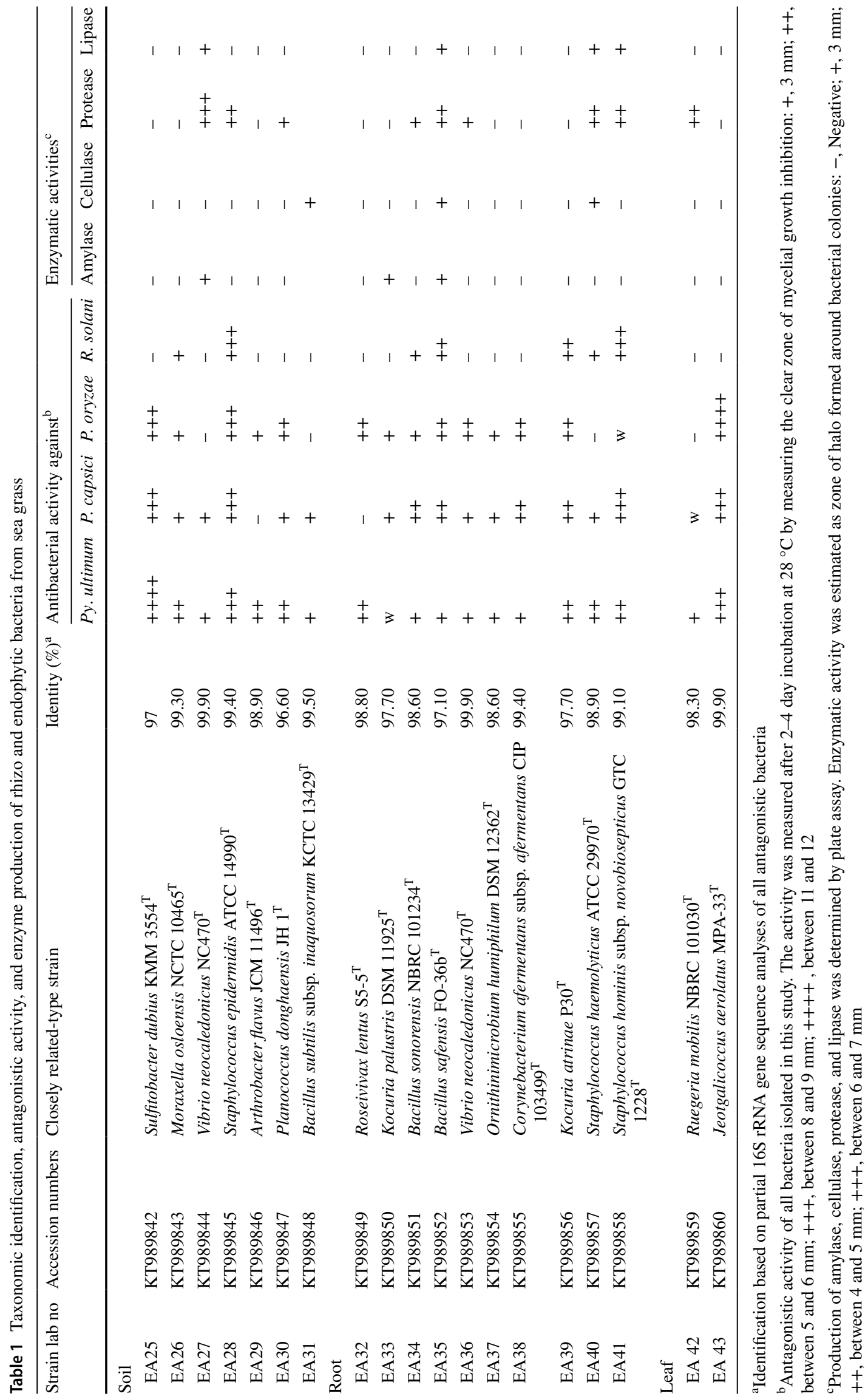



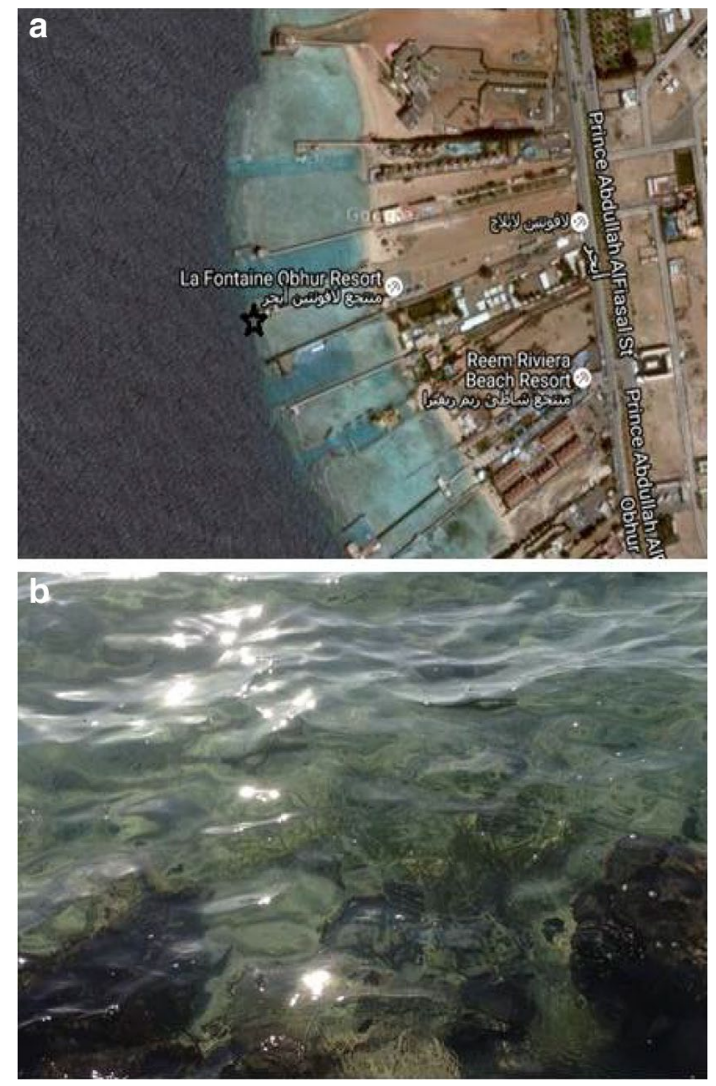

Fig. 1 Map and location of plant collection area from coastal are. a Location of coastal area of Jeddah, Saudi Arabia, used for plant collection marked with asterisk. b Photographic image of site from where plant specimen was collected. Map of the Obhur region was generated from maphill (http://www.maphill.com)

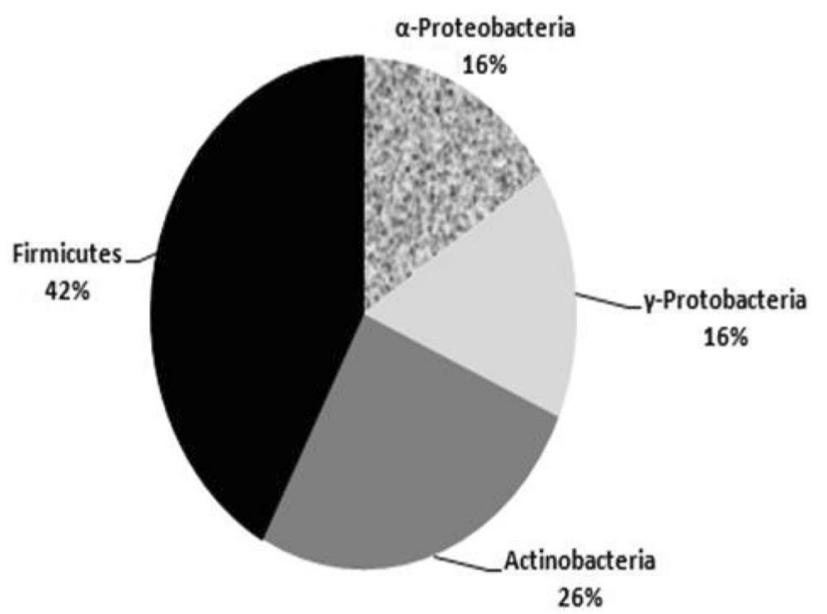

Fig. 2 Percentage composition of different phyla of antagonistic rhizo and endophytic bacteria isolated from marine grass on the basis of 16S rRNA gene sequence similarity

\section{Production of hydrolytic enzymes by antagonistic bacteria}

Furthermore, these antagonistic bacteria were considered for their production of hydrolyzing enzymes (amylase, cellulase, protease, and lipase) (Table 1). High proportion of antagonistic bacteria exhibited protease activity $(n=9 ; 47.3 \%)$ as compared to other enzymatic activities. Members of phylum Firmicutes such as EA27, EA28, EA35, EA, 40, and EA42 had stronger protease activity. The antagonistic strain EA28 displayed strong inhibitory activity against fungal pathogens and showed strong protease activity as well. Lipase production was observed at lower rate as compared to protease activity $(n=4 ; 21 \%)$. Three Firmicutes strains EA35, EA40, and EA42 and one $\gamma$-Proteobacteria strain EA27 showed lipase activity. Cellulase activity $(n=3 ; 15.7 \%)$ was observed only in strain EA27, EA33, and EA35, belonged to $\gamma$-Proteobacteria, Actinobacteria, and Firmicutes.

\section{Discussion}

Our objective was to isolate rhizo and endophytic bacteria from sea grass and to determine their antagonistic potential, taxonomic identity, and enzymatic activities. In this study, the nutrient media used for isolation of rhizo and endophytic bacteria effectively influenced the number of bacteria cultured. From soil, maximum numbers of bacteria were cultivable on ZMA, while more bacterial isolates were counted from roots and leaves on $1 / 2 \mathrm{R} 2 \mathrm{~A}$. Complex media contain more nutrients that allow fastidious bacteria to grow, while minimal media contain lower concentration of nutrients hence allow slow growing bacteria to grow (Hottes et al. 2004; Majzlik et al. 2011). While some slow growing bacteria need prolong period for growth on minimal media (Connon and Giovannoni 2002; Alain and Querellou 2009). In this study, the numbers of bacteria were highest on $1 / 2 \mathrm{R} 2 \mathrm{~A}$ as compared to other two media used for culturing. Different rhizo and endophytic bacterial species can be cultivated from plants depending on the culturing media used for isolation, incubation conditions.

Sea grasses not only provide food for different marine organisms, but also harbour different bacterial communities as evident from the present study. In this study, more rhizospheric bacteria were isolated from sea grass, but they are less antagonistic than endophytic bacteria, where more antagonistic endophytic bacteria recover from root tissues of sea grass. Several previous studies also reported endophytic bacteria as potential candidates to defend host plant against invading pathogens (Podolich et al. 2015). Endophytes are more beneficial than rhizospheric antagonist-counterparts due to their ability to enter the host plant and trigger host defense system. Being inside host, they protect host against

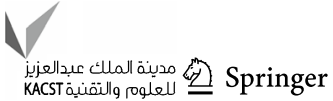


different pathogens by production of active compounds (Thomas and Upreti 2014). In this study from sea grass, 162 bacteria were isolated. Their screening on the basis of antifungal activity results in 19 antagonistic bacteria. Bacterial identification on the basis of $16 \mathrm{~S}$ rRNA gene sequence is a standard method for identification. These antagonistic bacteria further were identified on the basis of $16 \mathrm{~S}$ rRNA gene sequence and belong to Firmicutes, Actinobacteria, $\alpha$-Proteobacteria, and $\gamma$-Proteobacteria.

The phylogenetic analysis using $16 \mathrm{~S}$ rRNA gene sequence, group all rhizo and endophytic bacteria into four phyla, Firmicutes (Bacillus, Staphylococcus, Jeotgalicoccus,

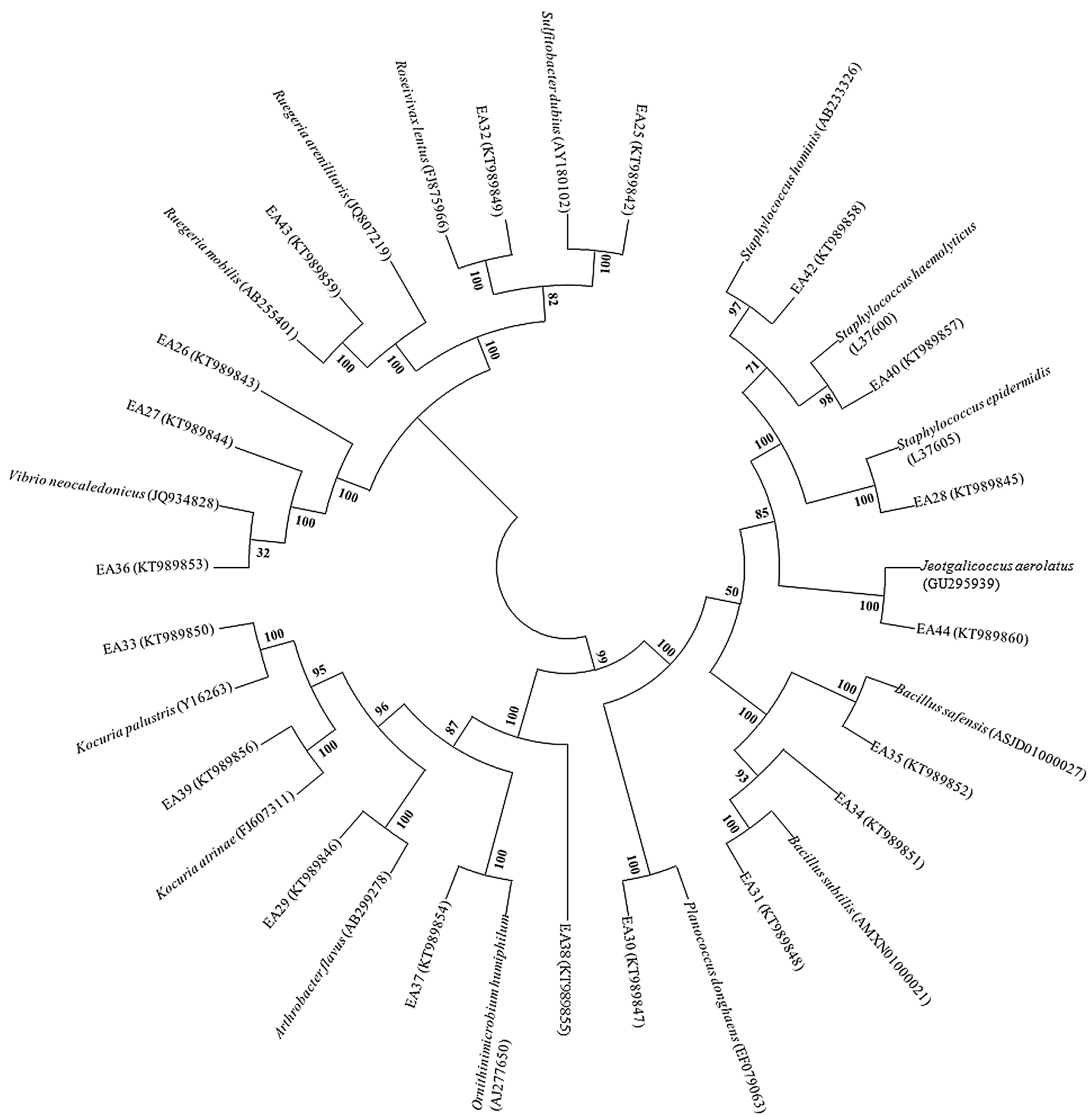

Fig. 3 Phylogenetic distribution of antagonistic bacteria isolated from marine grass on the basis of 16S rRNA gene sequences obtained from rhizo and endophytic bacteria and closely related sequences of the type strains of other species. The phylogenetic relationships were inferred from the 16S rRNA gene using the neighbor-joining method from distances computed with the Jukes-Cantor algorithm. Bootstrap values (1000 replicates) are shown next to the branches. GenBank accession numbers for each sequence are shown in parentheses. Bar, 0.01 accumulated changes per nucleotide 
and Planococcus), Actinobacteria (Kocuria, Arthrobacter, Ornithinimicrobium, and Corynebacterium), $\alpha$-Proteobacteria (Sulfitobacter, Roseivivax, and Ruegeria), and $\gamma$-Proteobacteria (Moraxella and Vibrio) (Figs. 2, 3). Our results indicated that Firmicutes was the most dominant group. Bacteria belonging to genus Bacillus were more common in both rhizo and endophytic bacteria isolated in this study. Antagonistic properties of Firmicutes from marine environment are already reported (Thomas et al. 2010; Mondol et al. 2013). Species of Bacillus are easy to culture and can survive under harsh conditions. Bioactive metabolite and enzyme production is common feature of Bacillus species (Mondol et al. 2013; Sinimol et al. 2016). In addition to Bacillus, Staphylococcus is another representative of Firmicutes in this study, and is already known to produce antimicrobial metabolites (Barbieri et al. 2005; Mani et al. 2016). The second phylum of this study Actinobacteria was recovered from both soil and root of the sea grass. Actinobacteria both in terrestrial and marine environment are rich source of antibiotic production and are resistant to different fungal and bacterial pathogens (Manivasagan et al. 2014; Hamedi et al. 2015). In this study, most of the Actinobacteria were isolated from roots of the sea grass. There is diversity in Actinobacteria spp. of root as they belong to different genera and are different from Actinobacteria isolated from rhizosphere in this study.

In this study, $32 \%$ of the antagonistic bacteria belong to two groups of Proteobacteria, $\alpha$-Proteobacteria, and $\gamma$-Proteobacteria. Species of different genera, Sulfitobacter, Roseivivax, and Ruegeria mainly belong to $\alpha$-Proteobacteria. Strains belong to Sulfitobacter and Ruegeria and vibrio already reported for antimicrobial activities (Desriac et al. 2013; Blunt et al. 2015). While for Roseivivax and Moraxella spp., no such activity has been reported before.

Some antagonistic bacteria isolated in this study were also able to produce hydrolytic enzymes. These hydrolases producing bacteria mainly belong to Firmicutes. Most of the isolates exhibited proteolytic activity. Others showed cellulase, protease, and lipase activities. Production of these hydrolases indicates their potential to colonize root intracellularly by producing such hydrolytic enzymes. Strain EA35 belong to Firmicutes was positive for all enzymatic activities tested (Table 1). To the best of our knowledge, this is the first study ever presented from Saudi Arabia. Here, we isolated rhizo and endophytic bacteria from sea grass and checked their antifungal and enzymatic potential.

\section{Conclusion}

The objective of present study was to isolate and screen bacteria from sea grass for their antagonistic and enzymatic activities. Use of different media for culturing and further screening for antifungal activity results in diverse group of antagonistic rhizo and endophytic bacteria. Furthermore, enzymatic activities of these antagonistic bacteria confirm their potential role in defense of host plant against different pathogens. Overall, sea grass appears to be an important source of antagonistic bacteria that can be use for antibiotic production or as biocontrol agents. Our findings will provide a basis for further studies related to the microbiome of Red sea in Saudi Arabia.

Acknowledgements This work was funded by the Deanship of Scientific Research (DSR), King Abdulaziz University, Jeddah, under Grant No. (1433/141/430). The author, therefore, acknowledge with thanks DSR technical and financial support.

\section{Compliance with ethical standards}

Conflict of interest The authors declare that they have no conflict of interests.

\section{References}

Alain K, Querellou J (2009) Cultivating the uncultured: limits, advances and future challenges. Extremophiles 13(4):583-594

Bagwell CE, La Rocque JR, Smith GW, Polson SW, Friez MJ, Longshore JW, Lovell CR (2002) Molecular diversity of diazotrophs in oligotrophic tropical seagrass bed communities. FEMS Microbiol Ecol 39(2):113-119

Barbieri E, Gioacchini AM, Zambonelli A, Bertini L, Stocchi V (2005) Determination of microbial volatile organic compounds from Staphylococcus pasteuri against Tuber borchii using solid-phase microextraction and gas chromatography/ion trap mass spectrometry. Rapid Commun Mass Spectrom 19(22):3411-3415

Bhatnagar I, Kim SK (2010) Immense essence of excellence: marine microbial bioactive compounds. Mar Drugs 8(10):2673-2701

Bibi F, Yasir M, Song GC, Lee SY, Chung YR (2012) Diversity and characterization of endophytic bacteria associated with tidal flat plants and their antagonistic effects on oomycetous plant pathogens. Plant Pathol J 28(1):20-31

Blunt JW, Brent RC, Robert AK, Murray HGM, Michele RP (2015) Marine natural products. Nat Prod Rep 32(2):116-211

Chen YH, Kuo J, Sung PJ, Chang YC, Lu MC, Wong TY, Kuo FW (2012) Isolation of marine bacteria with antimicrobial activities from cultured and field-collected soft corals. World J Microbiol Biotechnol 28(12):3269-3279

Connon SA, Giovannoni SJ (2002) High-throughput methods for culturing microorganisms in very-low-nutrient media yield diverse new marine isolates. Appl Environ Microbiol 68(8):3878-3885

Desriac F, Jégou C, Balnois E, Brillet B, Chevalier PL, Fleury Y (2013) Antimicrobial peptides from marine proteobacteria. Mar Drugs 11(10):3632-3660

García-Martínez M, Kuo J, Kilminster K, Walker DI, Rosselló-Mora R, Duarte CM (2005) Microbial colonization in the seagrass Posidonia spp. roots. Mar Biol Res 1(6):388-395

Garcias-Bonet N, Arrieta JM, Duarte CM, Marbà N (2016) Nitrogenfixing bacteria in Mediterranean seagrass (Posidonia oceanica) roots. Aquat Bot 131:57-60

Hall T (1999) BioEdit: a user-friendly biological sequence alignment editor and analysis program for Windows 95/98/NT. Nucleic Acids Symp Ser 41:95-98

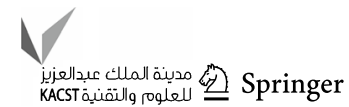


Hamedi J, Mohammadipanah F, Panahi HKS (2015) Halophiles. Biotechnological exploitation of actinobacterial members. Springer International Publishing, NewYork, pp 57-143

Harvey AL (2008) Natural products in drug discovery. Drug Discov Today 13(19):894-901

Hendricks CW, Doyle JD, Hugley B (1995) A new solid medium for enumerating cellulose-utilizing bacteria in soil. Appl Environ Microbiol 61(5):2016-2019

Hottes AK, Meewan M, Yang D, Arana N, Romero P, McAdams HH, Stephens C (2004) Transcriptional profiling of Caulobacter crescentus during growth on complex and minimal media. J Bacteriol 186(5):1448-1461

Hu Y, Chen J, Hu G, Yu J, Zhu X, Lin Y, Chen S, Yuan J (2015) Statistical research on the bioactivity of new marine natural products discovered during the 28 years from 1985 to 2012. Mar Drugs 13(1):202-221

Ireland CM, Copp BR, Foster MP, McDonald LA, Radisky DC, Swersey JC (1993) Pharmaceutical and bioactive natural products. Biomedical potential of marine natural products. Springer US, New York, pp 1-43

Jensen SI, Kühl M, Priem A (2007) Different bacterial communities associated with the roots and bulk sediment of the seagrass Zostera marina. FEMS Microbio Ecol 62(1):108-117

Kumar S, Karan R, Kapoor S, Singh SP, Khare SK (2012) Screening and isolation of halophilic bacteria producing industrially important enzymes. Braz J Microbio 43(3):1595-1603

Majzlik P, Strasky A, Adam V, Nemec M, Trnkova L, Zehnalek J, Kizek R (2011) Influence of zinc(II) and copper(II) ions on Streptomyces bacteria revealed by electrochemistry. Int J Electrochem Sci 6:2171-2191

Mani P, Dineshkumar G, Jayaseelan T, Deepalakshmi K, Kumar CG, Balan SS (2016) Antimicrobial activities of a promising glycolipid biosurfactant from a novel marine Staphylococcus saprophyticus SBPS 15. 3 Biotech 6(2):163

Manivasagan P, Venkatesan J, Sivakumar K, Kim SK (2014) Pharmaceutically active secondary metabolites of marine actinobacteria. Microbiol Res 169(4):262-278

Marhaeni B, Radjasa OK, Khoeri MM, Sabdono A, Bengen DG, Sudoyo H (2011) Antifouling activity of bacterial symbionts of seagrasses against marine biofilm-forming bacteria. J Environ Prot 2(9): 1245
Mondol MAM, Shin HJ, Islam MT (2013) Diversity of secondary metabolites from marine Bacillus species: chemistry and biological activity. Mar Drugs 11(8):2846-2872

Newman DJ, Cragg GM (2004) Marine natural products and related compounds in clinical and advanced preclinical trials. J Nat Prod 67(8):1216-1238

Pereg LL, Lipkin Y, Sar N (1994) Different niches of the Halophila stipulacea seagrass bed harbor distinct populations of nitrogen fixing bacteria. Mar Biol 119(3):327-333

Podolich O, Ardanov P, Zaets I, Pirttilä AM, Kozyrovska N (2015) Reviving of the endophytic bacterial community as a putative mechanism of plant resistance. Plant Soil 388(1-2):367-377

Shin DS, Park MS, Jung S, Lee MS, Lee KH, Bae KS, Kim SB (2007) Plant growth-promoting potential of endophytic bacteria isolated from roots of coastal sand dune plants. J Microbiol Biotechnol 17(8):1361-1368

Singh RP, Reddy CRK (2014) Seaweed-microbial interactions: key functions of seaweed-associated bacteria. FEMS Microbiol Ecol 88(2):213-230

Sinimol S, Sarika AR, Nair AJ (2016) Diversity and antagonistic potential of marine microbes collected from south-west coast of India. 3 Biotech 6(1):1-9

Tamura K, Stecher G, Peterson D, Filipsk A, Kumar S (2013) MEGA6: molecular evolutionary genetics analysis version 6.0. Mol Biol Evol 30(12):2725-2729

Thomas P, Upreti R (2014) Testing of bacterial endophytes from nonhost sources as potential antagonistic agents against tomato wilt pathogen Ralstonia solanacearum. Adv Microbiol 4:656-666

Thomas TRA, Kavlekar DP, LokaBharathi PA (2010) Marine drugs from sponge-microbe association-A review. Mar Drugs 8(4):1417-1468

Thompson JD, Gibson TJ, Plewniak F, Jeanmougin F, Higgins DG (1997) The CLUSTAL_X windows interface: flexible strategies for multiple sequence alignment aided by quality analysis tools. Nucleic Acids Res 25(24):4876-4882

Zidorn C (2016) Secondary metabolites of seagrasses (Alismatales and Potamogetonales; Alismatidae): chemical diversity, bioactivity, and ecological function. Phytochemistry 124:5-28 